University of Nebraska - Lincoln

DigitalCommons@University of Nebraska - Lincoln

USDA National Wildlife Research Center - Staff Publications
U.S. Department of Agriculture: Animal and Plant Health Inspection Service

2009

\title{
Invasive Litter, Not an Invasive Insectivore, Determines Invertebrate Communities in Hawaiian Forests
}

\author{
Nathania C. Tuttle \\ Utah State University, Logan, Department of Wildland Resources and the Ecology Center \\ Karen H. Beard \\ Utah State University, Logan, Department of Wildland Resources and the Ecology Center, \\ karen.beard@usu.edu \\ William C. Pitt \\ USDA-APHIS-Wildlife Services
}

Follow this and additional works at: https://digitalcommons.unl.edu/icwdm_usdanwrc

Part of the Environmental Sciences Commons

Tuttle, Nathania C.; Beard, Karen H.; and Pitt, William C., "Invasive Litter, Not an Invasive Insectivore, Determines Invertebrate Communities in Hawaiian Forests" (2009). USDA National Wildlife Research Center - Staff Publications. 949.

https://digitalcommons.unl.edu/icwdm_usdanwrc/949

This Article is brought to you for free and open access by the U.S. Department of Agriculture: Animal and Plant Health Inspection Service at DigitalCommons@University of Nebraska - Lincoln. It has been accepted for inclusion in USDA National Wildlife Research Center - Staff Publications by an authorized administrator of DigitalCommons@University of Nebraska - Lincoln. 


\title{
Invasive litter, not an invasive insectivore, determines invertebrate communities in Hawaiian forests
}

\author{
Nathania C. Tuttle $\cdot$ Karen H. Beard • \\ William C. Pitt
}

Received: 17 December 2007 / Accepted: 5 June 2008/Published online: 21 June 2008

(C) Springer Science+Business Media B.V. 2008

This article is a U.S. government work, and is not subject to copyright in the United States.

\begin{abstract}
In Hawaii, invasive plants have the ability to alter litter-based food chains because they often have litter traits that differ from native species. Additionally, abundant invasive predators, especially those representing new trophic levels, can reduce prey. The relative importance of these two processes on the litter invertebrate community in Hawaii is important, because they could affect the large number of endemic and endangered invertebrates. We determined the relative importance of litter resources, represented by leaf litter of two trees, an invasive nitrogen-fixer, Falcataria moluccana, and a native tree, Metrosideros polymorpha, and predation of an invasive terrestrial frog, Eleutherodactylus coqui, on leaf litter invertebrate abundance and composition. Principle component analysis revealed that F. moluccana litter creates an invertebrate community that greatly differs from that found in $M$. polymorpha litter. We found that $F$. moluccana increased the abundance of non-native fragmenters (Amphipoda and Isopoda) by $400 \%$ and non-native predaceous ants (Hymenoptera: Formicidae) by
\end{abstract}

N. C. Tuttle $\cdot$ K. H. Beard $(\bowtie)$

Department of Wildland Resources and the Ecology

Center, Utah State University, Logan, UT 84322-5230,

USA

e-mail: karen.beard@usu.edu

W. C. Pitt

USDA/APHIS/WS/National Wildlife Research Center,

Hilo Field Station, Hilo, HI 96721, USA
200\%. E. coqui had less effect on the litter invertebrate community; it reduced microbivores by $40 \%$ in F. moluccana and non-native ants by $30 \%$ across litter types. E. coqui stomach contents were similar in abundance and composition in both litter treatments, despite dramatic differences in the invertebrate community. Additionally, our results suggest that invertebrate community differences between litter types did not cascade to influence $E$. coqui growth or survivorship. In conclusion, it appears that an invasive nitrogen-fixing tree species has a greater influence on litter invertebrate community abundance and composition than the invasive predator, E. coqui.

Keywords Biological invasions ·

Bottom-up control · Eleutherodactylus coqui . Leaf litter · Top-down control · Trophic cascade

\section{Introduction}

Invasive plant species, which have traits that are distinctly different than those of native species, can greatly change community structure and ecosystem processes where they invade (Chapin et al. 1996; Vitousek 1986). These changes are particularly likely to occur in Hawaii, where native species have evolved in soils with very low nitrogen $(\mathrm{N})$ concentrations (Goergen and Daehler 2001). Indeed, N-fixers have been extremely successful invaders on infertile soils in 
Hawaii, where they have increased $\mathrm{N}$ inputs and cycling rates (Hughes and Denslow 2005; Vitousek and Walker 1989). The associated increase in $\mathrm{N}$ availability has been found to increase the growth, establishment, and spread of non-natives (Hughes and Denslow 2005; Vitousek and Walker 1989), and change the composition and activity of microbial communities (Allison et al. 2006). All of these changes can occur at the detriment of some native plant species, which are relatively unresponsive to $\mathrm{N}$ and phosphorus (P) addition (Ostertag and Verville 2002).

As an example, Falcataria moluccana [(Miquel) Barneby and Grimes] is a rapid-growing, N-fixing tree that was introduced from Indonesia in 1917 (Wagner et al. 1990). This tree is currently invading the few remaining native-dominated wet lowland forests in eastern Hawaii (Hughes and Uowolo 2006). As a result of the invasion, there has been an increase in $\mathrm{N}$ and $\mathrm{P}$ availability in the soil (Hughes and Denslow 2005), litterfall rates (Hughes and Denslow 2005), and leaf litter decomposition rates (Hughes and Uowolo 2006). Also, non-native $\mathrm{N}$-fixing plants might alter litter-based food chains, which are thought to be classic examples of extreme bottom-up control (Ponsard et al. 2000). Many studies have found that different plants support different litter invertebrate organisms (Wardle 2002); therefore, non-native plant invasions should alter invertebrate community abundance and composition. However, relatively few studies have examined changes in litter invertebrate community composition as a result of non-native plant invasions, and this could be particularly important in Hawaii, where there are more than 5,000 endemic arthropod species (Eldredge and Evenhuis 2002).

Bottom-up influences, however, do not prevent the possibility of top-down influences at higher trophic levels (Ponsard et al. 2000). Eleutherodactylus coqui Thomas, a terrestrial frog endemic to Puerto Rico, was accidentally introduced into Hawaii around 1988 via the horticulture trade (Kraus et al. 1999). This species is of concern because it is able to reach densities up to $89,000 /$ ha in some locations in Hawaii (Woolbright et al. 2006), and thus could be consuming an estimated 675,000 invertebrates (mostly litter invertebrates) ha $^{-1}$ night $^{-1}$ (Beard 2007). Additionally, research suggests that $E$. coqui can reduce invertebrate prey (Beard et al. 2003; Sin et al. 2008; Stewart and Woolbright 1996). Thus, its predation effects on native invertebrates are of concern, and need to be determined. Alternatively, invasive plants that alter the leaf litter invertebrate community (Ponsard et al. 2000; Rosemond et al. 2001; Wallace et al. 1999) may improve the prey base for E. coqui. Thus, it also should be determined if litter resources are an important factor contributing to the establishment and abundance of E. coqui.

The objective of this study was to compare the relative importance of litter resources, represented by leaf litter of the non-native, F. moluccana, and the native tree, Metrosideros polymorpha, and predation of $E$. coqui on leaf litter invertebrate abundance and composition in a Hawaiian lowland forest. Because litter resources are expected to exert extreme bottomup control, we also investigate whether potential changes in the invertebrate community cascade to influence the growth and survivorship of E. coqui. We also determine the relative importance of the two leaf litter types and E. coqui on leaf litter decomposition rates.

\section{Methods}

Study site

We conducted the experiment in a tropical wet forest in the Nanawale Forest Reserve (NFR) on the Island of Hawaii, USA (19 28' N, $15454^{\prime} \mathrm{W}, 230 \mathrm{~m}$ elevation). The site receives $3,000-4,000 \mathrm{~mm}$ of precipitation annually, with peak rainfall occurring between November and April (Giambelluca et al. 1986). The mean annual temperature is $23^{\circ} \mathrm{C}$ (Nullet and Sanderson 1993) with little seasonal variation (Price 1983). The site occurs on a rough a' a lava flow substrate that is 400 years old (Wolfe and Morris 1996). Dominant overstory vegetation includes Psidium cattleianum Sabine, M. polymorpha Gaud, and $F$. moluccana. Understory dominants include Cibotium sp., Melastoma candidum D. Don, and Clidemia hirta (L.) D. Don.

\section{Experimental design}

To control the source pool of invertebrates and environmental factors, we conducted a common garden experiment, with a $2 \times 2$ full factorial design, with leaf litter of overstory plants ( $F$. moluccana or $M$. polymorpha) and E. coqui (presence or absence) 
as the main factors $(n=10$ for each treatment combination). We conducted the experiment for 5 months, August through December 2005. We deemed this length of time as sufficient because invertebrate community responses to litter treatments in tropical wet lowland forests (Heneghan et al. 1999) and differences in leaf litter decomposition rates between F. moluccana and M. polymorpha in Hawaiian wet lowland forests (Hughes and Uowolo 2006) have been observed within this time period.

We randomly placed a total of $40,1-\mathrm{m}^{3}$ enclosures constructed of PVC frame $(2.5 \mathrm{~cm}$ diameter) and covered on all sides with plastic mesh with $0.76 \times 0.76-\mathrm{cm}$ openings, (BF Products, Harrisburg, Pennsylvania) in a $35 \times 65-\mathrm{m}$ area on the forest floor. The mesh size allows passage of all leaf litter invertebrates found on site (Beard, unpubl. data) and prevents passage of adult E. coqui $>26.2-\mathrm{mm}$ SVL (snout-vent length). There were smaller frogs at the study site that could freely move into and out of the enclosures. We could not exclude these frogs from moving into the enclosures because they are similar in size to many invertebrates found at the study site. However, we found very few small frogs (often 6$10 \mathrm{~mm} \mathrm{SVL}$ ) in the enclosures over the course of the experiment. Light levels and temperature inside the enclosures were not different from the surrounding environment. We deemed the enclosure size appropriate because $E$. coqui have small territory sizes and do not disperse over the course of several years (Woolbright 1985), and studies have found this enclosure size appropriate for measuring invertebrate responses to frogs (Beard et al. 2003; Sin et al. 2008) and leaf litter (Hansen 2000).

\section{Leaf litter treatment}

We collected newly senesced leaf litter from the forest floor under $F$. moluccana and $M$. polymorpha trees $<1 \mathrm{~km}$ from the experimental site. We considered yellow or red M. polymorpha leaves (Austin and Vitousek 2000) and yellow F. moluccana leaves on the forest floor newly senesced. M. polymorpha leaf size tends to be $5-10 \mathrm{~cm}^{2}$ (Joel et al. 1994). $F$. moluccana has bipinnately compound leaves; leaflets $\left(0.18-0.60 \mathrm{~cm}^{2}\right)$, rachises, and petioles were all considered part of the leaf $(22-30 \mathrm{~cm}$ long) (Jensen 1999). We placed air-dried leaf litter of each species on the floor of 20 randomly selected enclosures. Because $M$. polymorpha decomposes slower than $F$. moluccana, we initially placed $150 \mathrm{~g}$ of air-dried litter (136 g oven-dried) on the floor of each enclosure, which is within the range of naturally occurring $M$. polymorpha litter on the forest floor on the Island of Hawaii (oven-dried mass: 92$432 \mathrm{~g} \mathrm{~m}^{-2}$ ) (Crews et al. 2000). We added additional litter (16 g, air-dried mass) weekly to the floor of the enclosures, corresponding to a mean annual leaf litterfall rate for F. moluccana of $7 \mathrm{Mg} \mathrm{ha}^{-1}$ year $^{-1}$, which is a faster rate than that for M. polymorpha (0.25 $\mathrm{Mg} \mathrm{ha}^{-1}$ year $^{-1}$ ) (Hughes and Denslow 2005).

\section{Frog treatment}

We hand-captured frogs $<1 \mathrm{~km}$ from the experimental site. We placed seven frogs in each of 10 enclosures of each litter type to approximate natural densities [from a recent Hawaiian estimate of 28,000-89,000 frogs/ha (Woolbright et al. 2006)]. To standardize treatments and because male frogs are easier to identify than female frogs, we used adult male frogs to control for greater female growth rates (Woolbright 1989) and prey consumption rates (Beard 2007). We marked each frog uniquely using toe clipping, and weighed and measured each frog. We removed all live frogs from each enclosure between $2000 \mathrm{~h}$ and $2200 \mathrm{~h}$ at the end of each month, and restocked the enclosures with seven adult male frogs. We left dead frogs in enclosures. We recorded growth [SVL to the nearest $0.01 \mathrm{~mm}$ using a digital caliper and biomass to the nearest $0.01 \mathrm{~g}$ ] and survivorship of $E$. coqui on a monthly basis. We preserved removed frogs for subsequent stomach content analysis, in which we identified the invertebrates found in stomachs to order (family when possible).

Invertebrate community sampling

We collected invertebrates from a leaf litter tray $(16 \times 26 \mathrm{~cm}$ in area and $6 \mathrm{~cm}$ in height) every 2 weeks, and refilled the tray with an additional $20 \mathrm{~g}$ of air-dried leaf litter (the species assigned to the enclosure) in each enclosure. Trays had open tops, 15 openings $(8 \times 34 \mathrm{~mm}$ in area) on the sides, nine openings on the ends $(8 \times 34 \mathrm{~mm}$ in area), and 72 holes ( $4.5 \mathrm{~mm}$ diameter) arranged in a $6 \times 12$ grid on the bottom. The openings and holes were larger than all leaf litter invertebrates. We extracted invertebrates 
from the leaf litter with Berlese-Tullgren funnels in the laboratory within $2 \mathrm{~h}$. We identified all invertebrates collected to order (family when possible) and functional group for analysis: fragmenters (Amphipoda, Blattodea, Coleoptera, Dermaptera, Diplopoda, Gastropoda, Isopoda, and Psocoptera), microbivores (Acari, Collembola, and Diptera: Sciaridae), predators (Araneae, Chilopoda, Coleoptera: Staphylinidae, and Hymenoptera: Formicidae), and others (Coleoptera/ Diptera larvae, Coleoptera: Scolytidae, Diptera, Heteroptera, Homoptera, Hymenoptera: other, Lepidoptera, Oligochaeta, Orthoptera, and Thysanoptera). We based identifications on Borror et al. (1989).

\section{Leaf litter decomposition rates and chemistry}

We placed six decomposition bags $(n=240$ total, $15 \times 15 \mathrm{~cm}, 0.23 \times 0.23 \mathrm{~cm}$ mesh size), containing either $5 \mathrm{~g}$ of air-dried M. polymorpha leaves or $5 \mathrm{~g}$ of air-dried F. moluccana leaves, on the forest floor in each enclosure containing the same litter type. We oven-dried 20 initial subsamples ( $5 \mathrm{~g}$, air-dried) of each litter type ( $n=40$ total) at $70^{\circ} \mathrm{C}$ and weighed the subsamples to establish the relationship between airdried and oven-dried mass. After five months, we removed the decomposition bags from the enclosures, brushed them free of organic debris, oven-dried them at $70^{\circ} \mathrm{C}$, and weighed them. We then hand-collected invertebrates from each decomposition bag, preserved the invertebrates, and identified them to order (family when possible) and functional group. We ground decomposition bag contents and homogenized them with a 2-mm mesh screen. We ashed a $0.5 \mathrm{~g}$ subsample from each decomposition bag overnight at $500^{\circ} \mathrm{C}$ to develop an ash-free conversion factor (Harmon and Lajtha 1999). We analyzed two additional $0.5 \mathrm{~g}$ subsamples from each decomposition bag $(n=480)$ for total $\mathrm{C}$ and $\mathrm{N}$ using a LECO TruSpec $\mathrm{CN}$ analyzer (LECO, St. Joseph, Michigan, USA), and we corrected them for $\mathrm{C}$ and $\mathrm{N}$ contamination from soil. We also analyzed the initial subsamples of each litter type for total $\mathrm{C}$ and $\mathrm{N}$, and lignin using the $72 \%$ sulfuric acid procedure (Effland 1977).

\section{Statistical analysis}

To determine the effects of the treatments, litter (M. polymorpha and F. moluccana) and E. coqui (presence and absence), on the invertebrate community in leaf litter trays and decomposition bags, we used a two-way factorial ANOVA with repeated measures through time and a compound symmetry covariance structure in a completely randomized, split-plot design. We used a similar analysis for $E$. coqui stomach contents, except we used a oneway ANOVA without an E. coqui treatment. Response variables for these analyses were abundances of invertebrate orders (only data for those comprising more than $3 \%$ of samples are presented throughout), invertebrate functional group abundances, and principal component (PC) values from principal components analyses (PCA), when appropriate. We conducted a PCA on invertebrate taxa abundances to reduce the dimensions of leaf litter invertebrate samples, decomposition bag invertebrates, and E. coqui stomach contents. We tested ordinations with a random permutation test. When the test was significant, we present PC scores for axes explaining $>75 \%$ of the variation and loadings between -0.1 and 0.1 . We also conducted ANOVAs using these PC scores as response variables. For all ANOVAs, leaf litter type and frog (presence and absence), as appropriate, were fixed factors and enclosure was a random factor.

To determine E. coqui selection for each prey taxon relative to the abundance of each prey taxon in the environment (represented by leaf litter tray samples), we used Jacobs' prey electivity formula: $e_{i}=\left(p_{i}-p_{k}\right) /\left(\left(p_{i}+p_{k}\right)-\left(2 p_{i} p_{k}\right)\right)$, where $p_{i}$ is the proportion of each prey taxon in stomachs, and $p_{k}$ is the proportion of each prey taxon in the environment (Jacobs 1974). Electivity values range from -1 to +1 , where negative values indicate avoidance of a prey taxon, and positive values indicate preference. Mean $e_{i}$ values $<-0.70$ and $>0.70$ for invertebrate taxa are presented. We did not include adult Diptera in this analysis because leaf litter trays are not likely to adequately sample this order and results could show a biased preference.

To test for differences in $E$. coqui growth, we used a $2 \times 5$ factorial ANOVA with litter type as a fixed effect and enclosures were subjects measured repeatedly over time; month (1-5) was a within subject factor. The response variables were initial SVL and initial biomass expressed as a proportion of SVL and biomass, respectively, after one month; analyses conducted on differences in SVL and biomass not as a proportion showed similar results. We used a 
generalized linear model with a binomial distribution to test for differences in E. coqui survivorship. The response variable was the proportion of frogs that survived one month.

To test for differences in the fraction of leaf litter biomass remaining in decomposition bags, $\mathrm{C}$ and $\mathrm{N}$ concentrations, and $\mathrm{CN}$ ratio of decomposed litter, we used a two-way factorial ANOVA with a heterogeneous variance structure. We compared the $\mathrm{C}$ and $\mathrm{N}$ concentration and $\mathrm{CN}$ ratio of initial subsamples to that of decomposing litter using a one-way ANOVA for each litter type, with litter state (initial and decomposed) as fixed factors. We used a two tailed $t$ test to compare $\mathrm{C}, \mathrm{N}$, and lignin concentrations, percent moisture, and $\mathrm{CN}$ ratio between litter types in initial subsamples.

We conducted ANOVAs using PROC MIXED for all variables except for frog survivorship, which we conducted using PROC GLIMMIX, and we conducted $t$-tests using PROC TTEST in SAS/STAT v. 9.1.3 for Windows (SAS Institute 2006). We conducted PCAs using the pca function with a covariance matrix in the labdsv library $\mathrm{R}$ 2.0.1. To meet assumptions of normality and homogeneity, we logit-link transformed frog survivorship and inverse-square root transformed $\mathrm{CN}$ ratio. We considered $P<0.05$ significant, except for invertebrate samples, where we considered $P<0.10$ significant because we suspected high spatial and temporal variability (sensu Holmes and Schultz 1988).

\section{Results}

Invertebrate communities

We collected and identified a total of 97,541 invertebrates from enclosure leaf litter trays; samples across litter types and frog treatments mostly consisted of Isopoda (66\%), Amphipoda (11\%), Collembola (6\%), Acari (5\%), Coleoptera and Diptera larvae (5\%), and Hymenoptera: Formicidae (3\%). PCA showed there were differences among treatments (ordtest: $P=0.0001$; Fig. 1). PC1 loaded negatively on Isopoda $(-0.98)$ and Amphipoda $(-0.17)$, and the ANOVA on PC1 scores showed that there were more Amphipoda and Isopoda in F. moluccana than $M$. polymorpha (litter, $F_{1,21.8}=$ 88.50, $P<0.0001)$.

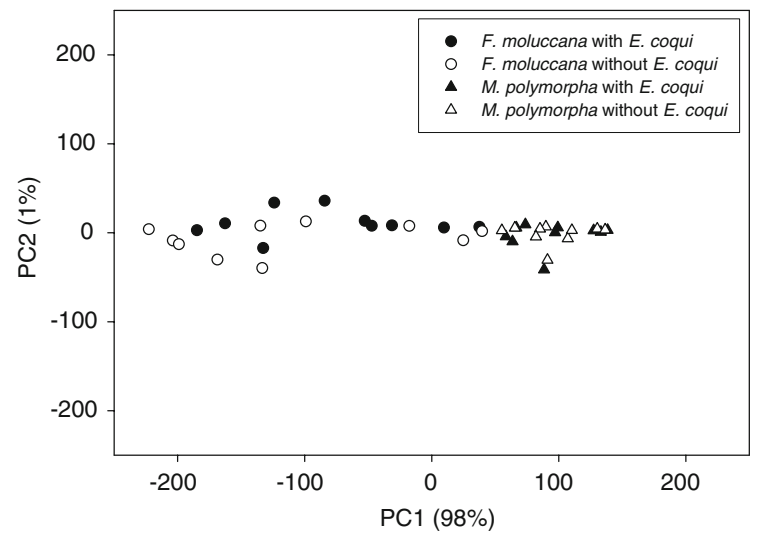

Fig. 1 Principal components analysis of invertebrates collected from semi-monthly leaf litter samples of Falcataria moluccana and Metrosideros polymorpha in enclosures with and without Eleutherodactylus coqui, Island of Hawaii, USA, 2005. Means were calculated by averaging samples across time (10 time periods) for each enclosure, and then averaging across treatments ( $n=10$ enclosures per treatment). Variance explained by $\mathrm{PC} 1$ and $\mathrm{PC} 2$ in parentheses

ANOVAs show that fragmenter (Fig. 2a; litter, $\left.F_{1,36}=97.45 ; P<0.0001\right)$ and predator abundance (Fig. 2b; litter, $F_{1,36}=15.44, P=0.0004$ ) was $400 \%$ and $200 \%$ greater, respectively, in $F$. moluccana than in M. polymorpha, but E. coqui had no effect on their abundance. We determined that $99 \%$ of the fragmenters were non-native (one Isopoda species, Porcellio laevis, and one Amphipoda species, Talitroides topitotum, D. Preston pers. comm.), and that $93 \%$ of the predators were non-native ants (Hymenoptera: Formicidae, R. Snelling, pers. comm.). When we repeated the predator analysis with only ants, we found that ant abundance was $200 \%$ greater in $F$. moluccana than in $M$. polymorpha (litter, $F_{1,36}=15.32, P=0.0004$ ), and $30 \%$ lower with $E$. coqui across litter types (frog, $\left.F_{1,36}=3.06, P=0.091\right)$. ANOVAs also show that there was a $40 \%$ microbivore reduction with $E$. coqui in $F$. moluccana (Fig. 2 c; litter $\times$ frog, $F_{1,36}=4.52$, $P=0.040)$. Of the microbivores, $52 \%$ were Collembola and $46 \%$ were Acari, which both had origin status (native or non-native) that we were unable to determine.

Analyses conducted on individual orders suggest that Amphipoda, Collembola, Isopoda, and Coleoptera/Diptera larvae were all greater in $F$. moluccana than in $M$. polymorpha, and that $E$. coqui reduced Collembola in $F$. moluccana (litter $\times$ frog, $\left.F_{1,36}=3.92, \quad P=0.056\right)$, reduced Hymenoptera: 
Fig. 2 Mean number of (a) fragmenters, (b) predators, and (c) microbivores $( \pm \mathrm{SE})$ in Falcataria moluccana and Metrosideros polymorpha samples in enclosures with and without Eleutherodactylus coqui, Island of Hawaii, USA, 2005. Means were calculated by averaging samples across time for each enclosure (10 time periods), and then averaging across treatments $(n=10$ enclosures per treatment). A different letter indicates a significant difference $(P<0.05)$
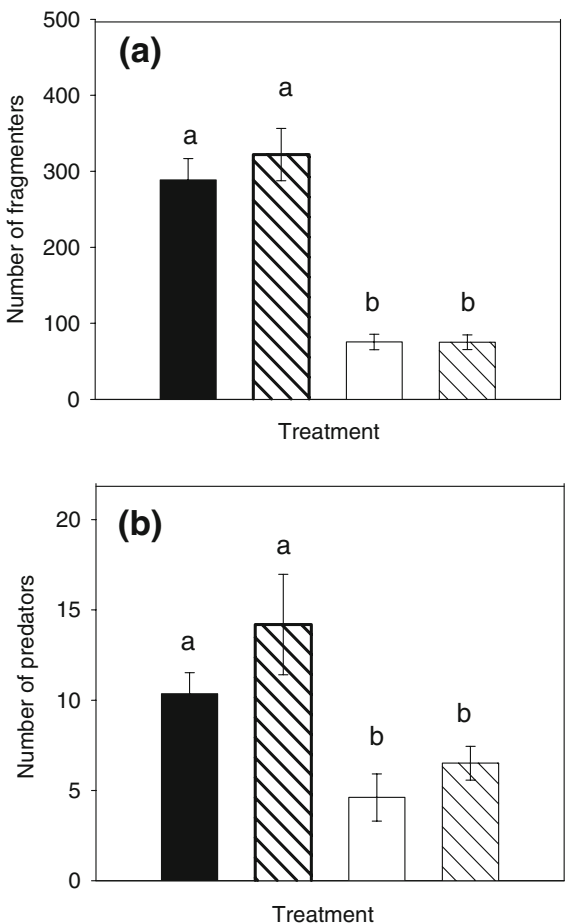
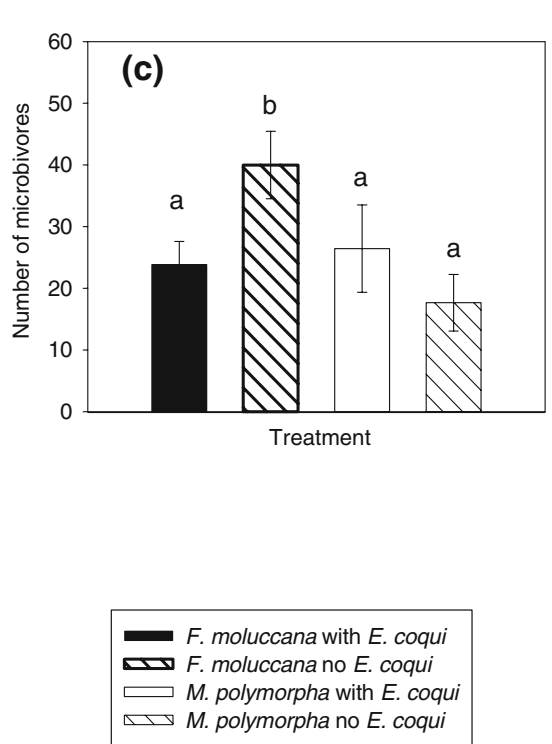

Formicidae across litter types, and increased Coleoptera/Diptera larvae across litter types (Table 1).

Frog prey, growth, and survivorship

We identified 1,411 invertebrates from 358 E. coqui stomachs. Dominant prey items included Amphipoda (45\%), Coleoptera: Scolytidae (10\%), Hymenoptera: Formicidae (7\%), Diptera (6\%), Coleoptera (5\%), and Isopoda $(5 \%)$. PCA showed there were no differences among treatments (ordtest: $P=0.68$;
Fig. 3). Furthermore, ANOVAs showed no differences between litter types for abundances of functional groups or invertebrate orders (Table 2).

Electivity analysis suggests $E$. coqui prefer Amphipoda in $F$. moluccana $(0.72)$ and $M$. polymorpha (0.73), avoid Isopoda in $F$. moluccana $(-0.94)$ and $M$. polymorpha $(-0.95)$, and avoid Coleoptera/Diptera larvae in F. moluccana $(-0.70)$.

Mean monthly E. coqui biomass decreased by $0.03 \pm 0.009 \mathrm{~g}$ and SVL increased by $1.01 \pm$ $0.001 \mathrm{~mm}$, and the mean proportion surviving monthly

Table 1 Mean invertebrate abundance $( \pm \mathrm{SE})$ for leaf litter invertebrate orders comprising $>3 \%$ of total invertebrates in leaf litter samples from enclosures with Falcataria moluccana and Metrosideros polymorpha, with and without Eleutherodactylus coqui

\begin{tabular}{|c|c|c|c|c|}
\hline \multirow[t]{2}{*}{ Order: Family } & \multicolumn{2}{|l|}{ F. moluccana } & \multicolumn{2}{|l|}{ M. polymorpha } \\
\hline & E. coqui & No E. coqui & E. coqui & No E. coqui \\
\hline Acari & $11.51(1.34)^{\mathrm{A}, \mathrm{A}}$ & $14.86(1.81)^{\mathrm{A}, \mathrm{A}}$ & $14.04(5.95)^{\mathrm{A}, \mathrm{A}}$ & $8.77(2.09)^{\mathrm{A}, \mathrm{A}}$ \\
\hline Amphipoda & $48.45(7.65)^{\mathrm{A}, \mathrm{A}}$ & $41.14(4.20)^{\mathrm{A}, \mathrm{A}}$ & $9.76(1.26)^{\mathrm{B}, \mathrm{A}}$ & $8.15(1.38)^{\mathrm{B}, \mathrm{A}}$ \\
\hline Coleoptera/Diptera larvae & $18.75(1.81)^{\mathrm{A}, \mathrm{A}}$ & $14.77(1.48)^{\mathrm{A}, \mathrm{B} *}$ & $6.52(0.59)^{\mathrm{B}, \mathrm{A}}$ & $5.75(0.75)^{\mathrm{B}, \mathrm{B}^{*}}$ \\
\hline Collembola & $11.58(3.15)^{\mathrm{A}, \mathrm{A}}$ & $24.62(5.85)^{\mathrm{A}, \mathrm{A}}$ & $11.84(5.29)^{\mathrm{B}^{*}, \mathrm{~A}}$ & $8.24(3.82)^{\mathrm{B}^{*}, \mathrm{~A}}$ \\
\hline Hymenoptera: Formicidae & $9.68(1.12)^{\mathrm{A}, \mathrm{A}}$ & $13.64(2.79)^{\mathrm{A}, \mathrm{B}^{*}}$ & $4.02(1.32)^{\mathrm{B}, \mathrm{A}}$ & $5.98(0.90)^{\mathrm{B}, \mathrm{B}^{*}}$ \\
\hline Isopoda & $237.14(23.24)^{\mathrm{A}, \mathrm{A}}$ & $278.41(31.27)^{\mathrm{A}, \mathrm{A}}$ & $63.84(9.37)^{\mathrm{B}, \mathrm{A}}$ & $64.69(8.89)^{\mathrm{B}, \mathrm{A}}$ \\
\hline Total & $350.56(25.14)^{\mathrm{A}, \mathrm{A}}$ & $401.45(29.97)^{\mathrm{A}, \mathrm{A}}$ & $116.38(7.70)^{\mathrm{B}, \mathrm{A}}$ & $106.95(7.57)^{\mathrm{B}, \mathrm{A}}$ \\
\hline
\end{tabular}

The first letter in superscript indicates a significant difference by litter treatment. The second letter indicates a significant difference by frog treatment. Significant interactions are discussed in the text. In all cases, $P<0.05$, except when noted, $* P<0.10$ 


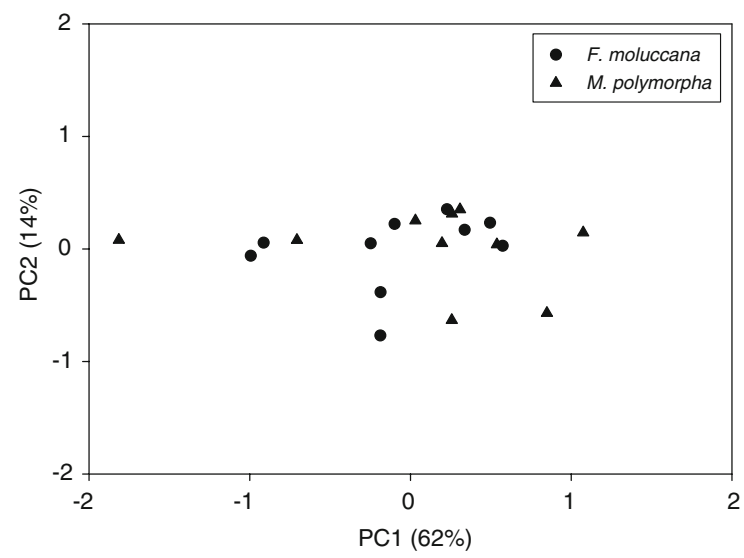

Fig. 3 Principal components analysis of invertebrates found in Eleutherodactylus coqui stomachs from enclosures with Falcataria moluccana $(n=10)$ and Metrosideros polymorpha $(n=10)$ leaf litter. Mean number of individuals in each invertebrate order was determined for all frogs surviving monthly ( $n=5$ months) in each enclosure, Island of Hawaii, USA, 2005. Means were calculated by averaging stomach contents across time for each enclosure, and then averaging across treatments. Variance explained by PC1 and PC2 in parentheses

Table 2 Mean invertebrate abundance $( \pm \mathrm{SE})$ for leaf litter invertebrate functional groups and orders comprising $>3 \%$ of total invertebrates in Eleutherodactylus coqui stomachs from enclosures with Falcataria moluccana and Metrosideros polymorpha

\begin{tabular}{lll}
\hline $\begin{array}{l}\text { Functional group } \\
\text { Order: Family }\end{array}$ & $\begin{array}{l}\text { F. moluccana } \\
n=177\end{array}$ & $\begin{array}{l}\text { M. polymorpha } \\
n=182\end{array}$ \\
\hline Fragmenters & $1.99(0.22)^{\mathrm{A}}$ & $1.94(0.30)^{\mathrm{A}}$ \\
$\quad$ Amphipoda & $1.67(0.21)^{\mathrm{A}}$ & $1.50(0.26)^{\mathrm{A}}$ \\
$\quad$ Coleoptera & $0.09(0.05)^{\mathrm{A}}$ & $0.17(0.09)^{\mathrm{A}}$ \\
$\quad$ Isopoda & $0.17(0.05)^{\mathrm{A}}$ & $0.14(0.04)^{\mathrm{A}}$ \\
Microbivores & $0.16(0.06)^{\mathrm{A}}$ & $0.19(0.05)^{\mathrm{A}}$ \\
$\quad$ Collembola & $0.09(0.04)^{\mathrm{A}}$ & $0.15(0.05)^{\mathrm{A}}$ \\
Predators & $0.43(0.22)^{\mathrm{A}}$ & $0.23(0.06)^{\mathrm{A}}$ \\
$\quad$ Hymenoptera: Formicidae & $0.37(0.22)^{\mathrm{A}}$ & $0.20(0.06)^{\mathrm{A}}$ \\
Other & $0.71(0.12)^{\mathrm{A}}$ & $1.33(0.33)^{\mathrm{A}}$ \\
$\quad$ Coleoptera: Scolytidae & $0.14(0.05)^{\mathrm{A}}$ & $0.74(0.32)^{\mathrm{A}}$ \\
$\quad$ Diptera & $0.20(0.06)^{\mathrm{A}}$ & $0.28(0.08)^{\mathrm{A}}$ \\
Total & $3.50(0.31)^{\mathrm{A}}$ & $3.97(0.36)^{\mathrm{A}}$
\end{tabular}

A different letter in superscript indicates a significant difference by litter treatment $(P<0.10)$

was $0.51 \pm 0.03$. There was no difference in proportional biomass change (litter, $F_{1,18}=1.07, P=0.31$ ), proportional SVL change (litter, $F_{1,18}=0.19$, $P=0.67$ ), or survivorship (litter, $F_{1,16.46}=0.25$, $P=0.62$ ) between frogs placed in the two litter types.
Leaf litter bag chemistry, invertebrates, and decomposition

Initial $F$. moluccana samples had a lower $\mathrm{C}$ concentration and $\mathrm{CN}$ ratio, and higher $\mathrm{N}$ and lignin concentration than initial $M$. polymorpha samples (Table 3). There was no difference between air-dried to oven-dried moisture content between the two litter types (Table 3). CN ratios were lower in decomposing litter than in initial subsamples in $F$. moluccana (litter state, $\left.F_{1,38}=312.81, P<0.0001\right)$ and $M$. polymorpha (litter state, $F_{1,38}=803.54, P<0.0001$ ).

We identified 18,178 invertebrates in the decomposition bags, which consisted primarily of Isopoda (52\%), Acari, suborder Oribatida (19\%), Amphipoda (10\%), Hymenoptera: Formicidae (9\%), and Coleoptera: Scolytidae (4\%). PCA showed there were no differences among treatments (ordtest: $P=0.52$ ). ANOVAs showed that there were more microbivores and predators, and more specifically, Acari: Oribatida, Coleoptera: Scolytidae, and Hymenoptera: Formicidae, in M. polymorpha decomposition bags than F. moluccana decomposition bags (Table 4). There were no differences in the invertebrate community with and without frogs by abundances of functional groups or invertebrate orders in the decomposition bags (Table 4).

F. moluccana leaf litter decomposed more rapidly than $M$. polymorpha (litter, $F_{1,20.1}=18.10, P=$ 0.0004). M. polymorpha decomposed faster with E. coqui, but there was no statistical support at our criterion level (litter $\times$ frog, $F_{1,18}=4.07, \quad P=$ 0.059), whereas decomposition for $F$. moluccana with and without $E$. coqui was non-significant (litter $\times$ frog, $F_{1,18}=0.02 ; P=0.89$ ).

Table 3 Mean initial chemical characteristics of Falcataria moluccana and Metrosideros polymorpha litter

\begin{tabular}{lcc}
\hline Litter chemistry & $\begin{array}{l}F . \text { moluccana } \\
n=20\end{array}$ & $\begin{array}{l}\text { M. polymorpha } \\
n=20\end{array}$ \\
\hline$\% \mathrm{C}$ & $50.26(0.09)^{\mathrm{A}}$ & $52.53(0.25)^{\mathrm{B}}$ \\
$\% \mathrm{~N}$ & $1.82(0.03)^{\mathrm{A}}$ & $0.42(0.006)^{\mathrm{B}}$ \\
C:N & $27.77(0.42)^{\mathrm{A}}$ & $126.10(1.98)^{\mathrm{B}}$ \\
$\%$ Lignin & $39.57(0.68)^{\mathrm{A}}$ & $32.83(0.56)^{\mathrm{B}}$ \\
$\%$ Moisture & $10.84(0.42)^{\mathrm{A}}$ & $9.63(0.65)^{\mathrm{A}}$
\end{tabular}

A different letter in superscript indicates a significant difference $(P<0.05)$ between litter types 
Table 4 Mean invertebrate abundance $( \pm$ SE) for leaf litter invertebrate functional groups and orders comprising $>3 \%$ of total invertebrates in decomposition bags from enclosures with
Falcataria moluccana and Metrosideros polymorpha, with and without Eleutherodactylus coqui

\begin{tabular}{|c|c|c|c|c|}
\hline \multirow{2}{*}{$\begin{array}{l}\text { Functional group } \\
\text { Order: Family }\end{array}$} & \multicolumn{2}{|l|}{ F. moluccana } & \multicolumn{2}{|l|}{ M. polymorpha } \\
\hline & E. coqui & No E. coqui & E. coqui & No E. coqui \\
\hline Fragmenters & $50.35(7.97)^{\mathrm{A}}$ & $53.60(9.68)^{\mathrm{A}}$ & $48.93(6.82)^{\mathrm{A}}$ & $41.95(5.08)^{\mathrm{A}}$ \\
\hline Amphipoda & $7.13(0.78)^{\mathrm{A}}$ & $7.83(1.29)^{\mathrm{A}}$ & $9.28(1.43)^{\mathrm{A}}$ & $7.28(1.25)^{\mathrm{A}}$ \\
\hline Isopoda & $41.82(7.71)^{\mathrm{A}}$ & $44.93(8.96)^{\mathrm{A}}$ & $38.42(6.40)^{\mathrm{A}}$ & $33.55(4.37)^{\mathrm{A}}$ \\
\hline Microbivores & $12.40(2.02)^{\mathrm{A}}$ & $10.37(3.29)^{\mathrm{A}}$ & $20.34(3.54)^{\mathrm{B}}$ & $16.85(2.55)^{\mathrm{B}}$ \\
\hline Acari & $12.31(2.02)^{\mathrm{A}}$ & $10.05(3.30)^{\mathrm{A}}$ & $20.16(3.52)^{\mathrm{B}}$ & $16.73(2.57)^{\mathrm{B}}$ \\
\hline Predators & $5.20(1.06)^{\mathrm{A}}$ & $4.02(1.01)^{\mathrm{A}}$ & $14.12(4.21)^{\mathrm{B}}$ & $8.59(2.07)^{\mathrm{B}}$ \\
\hline Hymenoptera: Formicidae & $4.52(0.96)^{\mathrm{A}}$ & $3.47(0.91)^{\mathrm{A}}$ & $13.28(4.11)^{\mathrm{B}}$ & $7.99(2.09)^{\mathrm{B}}$ \\
\hline Other & $3.57(0.77)^{\mathrm{A}}$ & $2.47(0.58)^{\mathrm{A}}$ & $7.16(2.80)^{\mathrm{A}}$ & $8.06(4.63)^{\mathrm{A}}$ \\
\hline Coleoptera: Scolytidae & $1.35(0.53)^{\mathrm{A}}$ & $0.58(0.20)^{\mathrm{A}}$ & $4.58(2.48)^{\mathrm{B}^{*}}$ & $6.52(4.57)^{\mathrm{B}^{*}}$ \\
\hline Total & $71.20(9.48)^{\mathrm{A}}$ & $70.47(13.40)^{\mathrm{A}}$ & $83.85(11.14)^{\mathrm{A}}$ & $74.24(9.73)^{\mathrm{A}}$ \\
\hline
\end{tabular}

A different letter in superscript indicates a significant difference by litter treatment. There are no differences by frog treatment. In all cases, $P<0.05$, except when noted, $* P<0.10$

\section{Discussion}

Our results suggest that litter resources of invasive plants have the potential to have a much greater impact on invertebrate abundance and community composition than the direct and indirect effects of a highly abundant invasive insectivore, such as E. coqui. More specifically, the findings show that $F$. moluccana leaf litter creates a very different invertebrate community than $M$. polymorpha leaf litter in the lowland forests of Hawaii, and that E. coqui did not have an effect of similar magnitude on the invertebrate community. In addition, we found that $F$. moluccana litter not only had the ability to change the invertebrate community, but also had the ability to greatly increase the abundance of nonnative invertebrates.

More specifically, we found that $F$. moluccana increased litter fragmenter abundance by $400 \%$ (99\% of which were non-native Isopoda and Amphipoda) and non-native predaceous ant (Hymenoptera: Formicidae) abundance by $200 \%$. Because we controlled for initial litter biomass, and samples were collected frequently (every 2 weeks), the most parsimonious explanation for this increase is the greater $\mathrm{N}$ and $\mathrm{P}$ concentrations, lower $\mathrm{CN}$ ratio, and greater leaf surface area per unit of litter biomass of newly senesced $F$. moluccana leaf litter compared to M. polymorpha (Hughes and Uowolo 2006).
In general, E. coqui had little effect on the litter invertebrate community, even though a diet study suggests that they mostly consume litter invertebrates in Hawaii (Beard 2007). Exceptions include a $40 \%$ decrease in microbivore abundance in F. moluccana, which likely resulted from a $54 \%$ decrease in Collembola abundance, and a $30 \%$ decrease in nonnative ant abundance across litter types. E. coqui also caused a $19 \%$ increase in Coleoptera/Diptera larvae across litter types. This may have occurred because this group largely feeds on frog carcasses.

Because there are many endemic invertebrates in Hawaii, it would be important to know whether these effects influence endemics. However, it is difficult to determine from our study the net effect of E. coqui on endemic Collembola in F. moluccana because, compared to $M$. polymorpha, $F$. moluccana increased Collembola abundance, and we could not determine the origin (i.e., native or non-native) of species in this order. E. coqui predation of non-native ants may benefit endemics, as ants are known to have a negative effect (i.e. predation and competition) on endemic invertebrates (Gillespie and Reimer 1993); however, our study did not permit such a comparison. Finally, we do not know the origin of Coleoptera and Diptera larvae, thus we do not know whether native or non-native larvae increased with $E$. coqui; although we could identify larvae in the family Culicidae (mosquitoes) because they are so distinct, 
and know that none of the larvae in our samples were in this family, which would be a result of significance in Hawaii (Beard and Pitt 2005).

Frog prey, growth, and survivorship

Prey items in E. coqui stomachs were surprisingly similar in $F$. moluccana and M. polymorpha litter, despite dramatic differences in invertebrate abundances. The lack of an increase in prey items in E. coqui stomachs with increased invertebrates in $F$. moluccana may have occurred because prey were not limiting in the enclosures; E. coqui was not able to utilize the increase in resources; or prey preferences created similar diets in the two litter types. Because we found no difference in the invertebrate taxa in E. coqui stomachs across litter types, the $54 \%$ reduction of Collembola in $F$. moluccana with E. coqui is, in part, likely due to indirect effects, such as a behavior response of Collembola to $E$. coqui or through a trophic cascade with another prey item.

Electivity analyses suggest that E. coqui prefer Amphipoda and avoid Isopoda across litter types. We might have expected prey preferences (i.e. for Amphipoda) to translate to differences in invertebrate abundances across litter types with $E$. coqui. However, it is likely that litter type masked these effects because following Isopoda, Amphipoda was the order second most influenced by litter type. The other preference may not be expected to result in differences with $E$. coqui across litter types because it was an avoidance. For example, Isopoda was a small portion (5\%) of their diet across litter types, even though it accounted for $66 \%$ of invertebrates collected from litter trays, and was four times more abundant in $F$. moluccana than M. polymorpha (Table 2).

Invertebrate community differences between litter types also did not influence $E$. coqui growth or survivorship. We expected that E. coqui growth and survivorship to be higher in $F$. moluccana because there were more invertebrates. There are several potential explanations for this finding. First, as previously mentioned, we found that $E$. coqui were not consuming more invertebrates in $F$. moluccana litter. Second, M. polymorpha leaves are much larger than $F$. moluccana leaflets, which might have provided E. coqui with more cover and reduced desiccation (Pough et al. 1983). Finally, because $E$. coqui mass and SVL changes were small in both litter types, if there was a difference in $E$. coqui growth between treatments, it might have been difficult to detect.

Leaf litter bag invertebrates and decomposition

The litter invertebrate community in the decomposition bags represents the invertebrate community present after five months of decomposition. After five months, all invertebrate groups that differed between litter types had greater abundances in $M$. polymorpha than $F$. moluccana. This likely occurred because there was a greater proportion of M. polymorpha $(55 \% \pm 0.64 \%)$ compared to $F$. moluccana $(48 \% \pm 1.6 \%)$ remaining in the bags, or because the chemical quality of $M$. polymorpha compared to $F$. moluccana could have increased over time. The lack of an E. coqui effect on invertebrates inside decomposition bags might be attributed to their inability to directly predate on these invertebrates or indirectly influence their behavior.

Previous research has suggested that leaf litter decomposition rates of $F$. moluccana and M. polymorpha are more a function of the dominant species in the forest stand than initial chemical composition, and that decomposition rates are faster in stands dominated by $F$. moluccana than those dominated by M. polymorpha (Hughes and Uowolo 2006). Our results differ in that we found that $F$. moluccana decomposed at a faster rate than $M$. polymorpha in a forest stand that had both species in the canopy. However, our study provides a hypothesis for the pattern observed by Hughes and Uowolo (2006). Our study suggests that decomposition rates could change as a function of the dominant tree species because litter invertebrate communities differ. More specifically, the great initial increase in fragmenters, which were many times more abundant than the other functional groups, in newly senesced $F$. moluccana litter compared to $M$. polymorpha litter, might increase decomposition rates in $F$. moluccana-dominated stands compared to $M$. polymorpha-dominated stands.

We found a lack of statistical support for an $E$. coqui effect on decomposition rates over five months in both litter types, despite previous studies showing that E. coqui increases decomposition rate in both Hawaii and Puerto Rico (Beard et al. 2003; Sin et al. 
2008). Although, the study showing that E. coqui increased $M$. polymorpha decomposition rates in Hawaii (Sin et al. 2008), only found a significant effect after 6 months, and not after 3 months, and this experiment was conducted for 5 months. The increase in decomposition rates with $E$. coqui has been attributed to an increase in nutrients in forms more available to microbes and fungi; more specifically, increased $\mathrm{N}$ and $\mathrm{P}$ availability from waste and carcasses (Beard et al. 2002). Thus, we expected that $E$. coqui would have a greater influence on decomposition rates of $M$. polymorpha than $F$. moluccana because $M$. polymorpha decomposition is more $\mathrm{N}$ and P-limited (Vitousek 1998). Our results do suggest that $E$. coqui is more likely to affect $M$. polymorpha decomposition rates than $F$. moluccana, because M. polymorpha decomposition with E. coqui was nearly significantly faster, while decomposition for $F$. moluccana with and without E. coqui was nonsignificant.

\section{Landscape-level implications}

We chose to conduct this experiment in a common garden to control the source pool of invertebrates and environmental factors. However, we do not know if the results of this controlled experiment represent landscape conditions. For example, we found that $F$. moluccana supports more invertebrates based on litter resources alone, but $F$. moluccana may support even more invertebrates in the environment due to greater canopy cover and faster litterfall rates (Hughes and Denslow 2005). Litter resources alone do not appear to improve the diet, growth, or survivorship of E. coqui, but other characteristics of $F$. moluccana, such as additional habitat structure (e.g. larger boles, more vines on boles, and greater tree height) for foraging and calling, and more shade, might support more E. coqui on a landscape-scale. Furthermore, in F. moluccana-invaded forests, both litter types are often available, so E. coqui may benefit from increased invertebrate abundance as a result of $F$. moluccana invasion, and from the additional cover provided by $M$. polymorpha leaf litter on the forest floor. Future research could determine whether our results correlate with landscape conditions, and if traits other than litter characteristics of $F$. moluccana and $M$. polymorpha explain differences in the invertebrate community and E. coqui densities in native and $F$. moluccanainvaded forests.

Acknowledgements Funding was provided by the Jack H. Berryman Institute and the Hawaii Invasive Species Council (Hawaii Department of Land and Natural Resources). We thank M. Higashi, M. Tuttle, A. Huff, J. Verlinde, K. Crowell, D. Grant, S. Bisrat, C. Richins, and S. Selamet for field and laboratory assistance; S. Durham for statistical advice; R. Ryel for vehicle use; and D. Preston and R. Snelling for invertebrate identification to species and origin. Procedures were performed with the approval of Utah State University's Institutional Animal Care and Use Committee permit number 1145R.

\section{References}

Allison SD, Nielsen C, Hughes RF (2006) Elevated enzyme activities in soils under the invasive nitrogen-fixing tree Falcataria moluccana. Soil Biol Biochem 38:1537-1544. doi:10.1016/j.soilbio.2005.11.008

Austin AT, Vitousek PM (2000) Precipitation, decomposition and litter decomposability of Metrosideros polymorpha in native forests on Hawai'i. J Ecol 88:129-138. doi: 10.1046/j.1365-2745.2000.00437.x

Beard KH (2007) Diet of the invasive frog, Eleutherodactylus coqui, in Hawaii. Copeia 2007:281-291. doi:10.1643/ 0045-8511(2007)7[281:DOTIFE]2.0.CO;2

Beard KH, Pitt WC (2005) Potential consequences of the coqui frog invasion in Hawaii. Divers Distrib 11:427-433. doi: 10.1111/j.1366-9516.2005.00178.x

Beard KH, Vogt KA, Kulmatiski A (2002) Top-down effects of a terrestrial frog on forest nutrient dynamics. Oecologia 133:583-593. doi:10.1007/s00442-002-1071-9

Beard KH, Eschtruth AK, Vogt KA, Vogt DJ, Scatena FN (2003) The effects of the frog Eleutherodactylus coqui on invertebrates and ecosystem processes at two scales in the Luquillo Experimental Forest, Puerto Rico. J Trop Ecol 19:607-617. doi:10.1017/S0266467403006011

Borror DJ, Triplehorn CA, Johnson NF (1989) An introduction to the study of insects. Saunders College Publishing, Philadelphia

Chapin FS III, Reynolds H, D'Antonio CM, Eckhart V (1996) The functional role of species in terrestrial ecosystems. In: Walker B, Steffen W (eds) Global change in terrestrial ecosystems. Cambridge University Press, Cambridge, pp 403-430

Crews TE, Farrington H, Vitousek PM (2000) Changes in asymbiotic, heterotrophic nitrogen fixation on leaf litter of Metrosideros polymorpha with long-term ecosystem development in Hawaii. Ecosystems (N Y, Print) 3:386385. doi: $10.1007 / \mathrm{s} 100210000034$

Effland MJ (1977) Modified procedure to determine acid insoluble lignin in wood and pulp. TAPPI 60:143-144

Eldredge LG, Evenhuis NL (2002) Numbers of Hawaiian species for 2000. Bish Mus Occas Pap 68:71-78

Giambelluca TW, Nullet MA, Schroeder PA (1986) Rainfall atlas of Hawai'i. Department of Land and Natural Resources, Honolulu 
Gillespie RG, Reimer N (1993) The effect of alien predatory ants (Hymenoptera: Formicidae) on Hawaiian endemic spiders (Araneae:Tetragnathidae). Pac Sci 47:21-33

Goergen E, Daehler CC (2001) Reproductive ecology of a native Hawaiian grass (Heteropogon contortus; Poaceae) versus its alien competitor (Pennisetum setaceum; Poaceae). Int J Plant Sci 162:317-326. doi:10.1086/319587

Hansen RA (2000) Effects of habitat complexity and composition on a diverse litter microarthropod assemblage. Ecology 81:1120-1132

Harmon ME, Lajtha K (1999) Analysis of detritus and organic horizons for mineral and organic constituents. In: Robertson GP, Coleman DC, Bledsoe CS, Sollins P (eds) Standard soil methods for long-term ecological research. Oxford University Press, New York, pp 143-165

Heneghan L, Coleman DC, Zou X, Crossely DA Jr, Haines BL (1999) Soil microarthropod contributions to decomposition dynamics: tropical-temperate comparisons of a single substrate. Ecology 80:1873-1882

Holmes RT, Schultz JC (1988) Food availability for forest birds: effects of prey distribution and abundance on bird foraging. Can J Zool 66:720-728

Hughes RF, Denslow JS (2005) Invasion by an N-2-fixing tree alters function and structure in wet lowland forests of Hawaii. Ecol Appl 15:1615-1628. doi:10.1890/04-0874

Hughes RF, Uowolo A (2006) Impacts of Falcataria moluccana invasion on decomposition in Hawaiian lowland wet forests: The importance of stand-level controls. Ecosystems (N Y, Print) 9:977-991. doi:10.1007/s10021005-0083-9

Jacobs J (1974) Quantitative measurement of food selection. Oecologia 14:413-417. doi:10.1007/BF00384581

Jensen M (1999) Trees commonly cultivated in Southeast Asia: An illustrated field guide. RAP Publication 13. Food and Agricultural Organization, Regional Office for Asia and the Pacific (RAP), Bangkok

Joel G, Aplet G, Vitousek PM (1994) Leaf morphology along environmental gradients in Hawaiian Metrosideros polymorpha. Biotropica 26:17-22. doi:10.2307/2389106

Kraus F, Cambell EW, Allison A, Pratt T (1999) Eleutherodactylus frog introductions to Hawaii. Herpetol Rev 30:21-25

Nullet D, Sanderson M (1993) Radiation and energy balances and air temperatures. In: Sanderson M (ed) Prevailing trade winds: weather and climate in Hawaii. University of Hawaii Press, Honolulu, pp 37-55

Ostertag R, Verville JH (2002) Fertilization with nitrogen and phosphorus increases abundance of non-native species in Hawaiian montane forests. Plant Ecol 162:77-90. doi: 10.1023/A: 1020332824836

Ponsard S, Arditi R, Jost C (2000) Assessing top-down and bottom-up control in a litter-based soil macroinvertebrate food chain. Oikos 89:524-540. doi:10.1034/j.16000706.2000.890312.x
Pough FH, Taigen TL, Stewart MM, Brussard PF (1983) Behavioral modification of evaporative water loss by a Puerto Rican frog. Ecology 64:244-252. doi:10.2307/ 1937072

Price S (1983) Climate. In: Armstrong RW (ed) Atlas of Hawaii. University of Hawaii Press, Honolulu, pp 59-66

Rosemond AD, Pringle CM, Ramirez A, Paul MJ (2001) A test of top-down and bottom-up control in a detritus based food web. Ecology 82:2279-2293

Sin H, Beard KH, Pitt WC (2008) An invasive frog, Eleutherodactylus coqui, increases new leaf production and leaf litter decomposition rates through nutrient cycling in Hawaii. Biol Invasions 10:335-345. doi:10.1007/s10530007-9133-x

Stewart MM, Woolbright LL (1996) Amphibians. In: Reagan DP, Waide RB (eds) The food web of a tropical rainforest. The University of Chicago Press, Chicago, pp 273-320

Vitousek PM (1986) Biological invasions and ecosystem properties: can species make a difference? In: Mooney HA, Drake JA (eds) Ecology of biological invasions of North America and Hawaii. Springer-Verlag, New York, pp 163-176

Vitousek PM (1998) Foliar and litter nutrients, nutrient resorption, and decomposition in Hawaiian Metrosideros polymorpha. Ecosystems (N Y, Print) 1:401-407. doi: 10.1007/s100219900033

Vitousek PM, Walker LR (1989) Biological invasion by Myrica faya in Hawaii: plant demography, nitrogen fixation, ecosystem effects. Ecol Monogr 59:247-265. doi: $10.2307 / 1942601$

Wagner WL, Herbst DR, Sohmer SH (1990) Manual of the flowering plants of Hawaii. University of Hawaii Press, Honolulu

Wallace JB, Eggert SL, Meyer JL, Webster JR (1999) Effects of resource limitation on a detrital-based ecosystem. Ecol Monogr 69:409-442

Wardle DA (2002) Communities and ecosystems: linking the aboveground and belowground components. Princeton University Press, Princeton

Wolfe EW, Morris J (1996) Geologic map of the Island of Hawaii. U.S. Geological Survey miscellaneous geologic investigations series map I-2524-A, scale 1:100, 000. USGS, Honolulu

Woolbright LL (1985) Patterns of nocturnal movement and calling by the tropical frog Eleutherodactylus coqui. Herpetologica 41:1-9

Woolbright LL (1989) Sexual dimorphism in Eleutherodactylus coqui: selection pressures and growth rates. Herpetologica 45:68-74

Woolbright LL, Hara AH, Jacobsen CM, Mautz WJ, Benevides FL Jr (2006) Population densities of the Coqui, Eleutherodactylus coqui (Anura: Leptodactylidae) in newly invaded Hawaii and in native Puerto Rico. J Herpetol 40:122-126. doi:10.1670/79-05W.1 